\title{
EFFECTS OF CAPITAL STRUCTURE, PROFITABILITY AND FIRM SIZE TOWARDS EARNING MANAGEMENT IN MANUFACTURING COMPANIES
}

\author{
Dian Primanita Oktasari \\ Management Study Program,Faculty of Economic and Business, Universitas Mercu Buana
}

Article DOI: https://doi.org/10.36713/epra4334

\begin{abstract}
This study aims to examine the effect of capital structure, profitability and company size on earnings management. The population in this study is companies with manufacturing types listed on the Indonesia Stock Exchange in the period 2013 to 2017. Samples were obtained using a purposive random sampling method. Data analysis uses fixed effects. The results showed that the capital structure, profitability and size of the company affect earnings management
\end{abstract}

\section{INTRODUCTION}

The development of the state of the economy in Indonesia is still not stable in line with the presidential election event, so the manufacturing industry market is currently experiencing a decline from the previous year. According to Arif (2016), influencing factors are due to a decrease in demand in key markets, increasing global trade tensions and the need to stay at the forefront of future technology. The manufacturing industry has become one of the important sectors in the development of a fairly stable national economy and is supporting the economy with a positive growth rate. With the current challenges, both internal and external challenges, the government needs to implement several strategies. These strategies are focused on how to create a manufacturing industry that is resilient to crisis shocks and industrial conditions or climate that can attract investors.

The phenomenon that often occurs in relation to earnings management usually arises due to a form of error and negligence of the subject of financial management itself, which is directly or indirectly influenced by various factors, both internal and external (Mahawyahrti and Budiasih, 2016).

Mahawyahrti and Budiasih, (2016) said that if a condition in which the management did not succeed in achieving the specified profit target, then management would utilize the flexibility allowed by accounting standards in preparing financial statements to modify reported earnings. Management will be motivated to show good performance in producing maximum value or profit for the company so that management tends to choose and apply accounting methods that can provide better earnings information.Salah satu yang menarik untuk ditelusuri adalah perilaku manajemen dalam melakukan praktik manajemen laba. Pentingnya informasi laba bagi para penggunanya menjadikan tiap perusahaan berlombalomba meningkatkan labanya. Namun bagi pihak tertentu ada yang melakukan cara tidak sehat guna mencapai tujuan individunya terhadap informasi laba perusahaan. Hal tersebut biasanya dijadikan praktek manipulasi laba yang dilakukan oleh manajemen perusahaan yang mengetahui kondisi didalam perusahaan (Dinda Dwi, 2019).

Management behavior that regulates earnings as above is usually known as earnings management. Earning management initially appears and is done by the compilers of financial statements in a company's financial reporting process because they expect a benefit from these actions (Mahawyahrti and Budiasih, 2016). Earnings management is one of the conditions where management intervenes in the process of preparing financial statements for external parties so that they can flatten, increase and decrease profits (Fathiani, 2016). If the company's earnings management is correct and in accordance with existing regulations, earnings management can be efficient, meaning that 
it can increase the informativeness of earnings in communicating personal information. However, if earnings management is not done in the right way then it can be opportunistic, meaning that earnings management reports its profits opportunistically to maximize its personal interests (Scott in Hartanto, 2011). Although some writers interpret earnings management in different languages, but thus have the same meaning of determining earnings in such a way by playing with the numbers in the financial statements of a company not based on the actual situation by obtaining expected profits.

\section{Problem Identification}

1. Does the capital structure affect earnings management?

2. Does profitability affect earnings management?

3. Does the size of the company affect earnings management?

\section{LITERATUR REVIEW Capital Structure}

According to Hery (2015) capital structure is the ratio or balance of long-term funding of the company which is shown by the ratio of long-term debt to equity. Meanwhile, according to Fahmi (2015) capital structure is a balance between the use of loan capital consisting of short-term debt that is permanent, long-term debt with own capital consisting of preferred shares and ordinary shares. Furthermore, according to Mulyawan (2015), the company's capital structure is a mixture or proportion of long-term debt and equity, in order to fund its investments (operating assets). Based on some of these references, the author can conclude that capital structure is an important issue for the company because of the good or bad capital structure will have a direct effect on the financial position of the company, especially with the existence of a very large debt will burden the company.

\section{Profitability}

Profitability according to Harahap (2015) is describing the ability of a company to get profits through all capabilities and existing resources such as sales, cash, capital, number of employees, number of branches of a company, and so forth. Meanwhile, according to Brigham and Houston (2009), profitability is the final result of a number of policies and decisions made by the company. Based on the opinions of the experts above, the conclusion can be drawn is the company's ability to generate profits by using existing resources within the company itself.

Profitability ratios according to Weston and Copeland (2010) are measuring the effectiveness of management based on the results of returns generated from sales and investments. Profitability ratio according to Kasmir (2016) is a ratio to measure how much the level of profit that can be obtained by the company. Based on the above theory it can be concluded that the profitability ratio is a ratio to measure how much a company is able to generate profits by using all the factors that the company is in to produce maximum profit.

\section{Firm Size}

According to Riyanto (2013) firm size is amount of equity, sales or asset values. According to Torang (2012), firm size is the size of the organization is a context variable that measures the demands of the service or product of the organization. Furthermore, according to Kasmir (2016) firm size is a scale where the size of the company can be classified according to various ways, including the size of income, total assets, and total capital. The greater the size of revenue, total assets, and total capital will reflect the company's condition that is getting stronger. Based on some of the above understanding, it can be seen that the size of the company is a scale that describes the size of the company with various values such as equity, sales, and company assets, the greater the value reflects a stronger company.

\section{Earning Management}

According to Scott (2012), opinion that earnings management is earning management intervention in the process of preparing financial statements for external parties so that they can flatten, increase, and decrease earnings reporting, where management can use the leeway of using accounting methods, making policies (discreationary) ) which can accelerate or delay costs and revenues, so that the company's profits are smaller or larger as expected. According to Kieso (2011) earnings management is defined as the time planning of revenues, expenses, gains and losses to flatten earnings fluctuations.

\section{Past Research And Framework}

There is a gap research regarding the effect of Capital Structure, Profitability and Company Size on Profit Management. Research conducted by Agustia and Elly (2018) and Indracahya and Dewi (2017) shows that the capital structure has a positive and significant effect on earnings management. The results of this study contradict the research conducted by Minabari, et al (2017) and Widianingrum and Sunarto (2017) that the Capital Structure has no significant effect on earnings management.

Research conducted by Agustia and Elly (2018) shows that profitability has no significant effect on earnings management. This is contrary to research conducted by Tata and Herman (2017) which shows that profitability has a positive and significant effect on earnings management.

Research conducted by Ali (2015) and Medyawati and Astri (2016) shows that company size has a positive and significant effect on earnings 


\section{EPRA International Journal of Research and Development (IJRD)}

Volume: 5 | Issue: 5 | May 2020

- Peer Reviewed Journal

management. This contrasts with research conducted by Kingsley, et al (2016) and Widianingrum and no significant effect on earnings management. Sunarto (2018) which shows that company size has

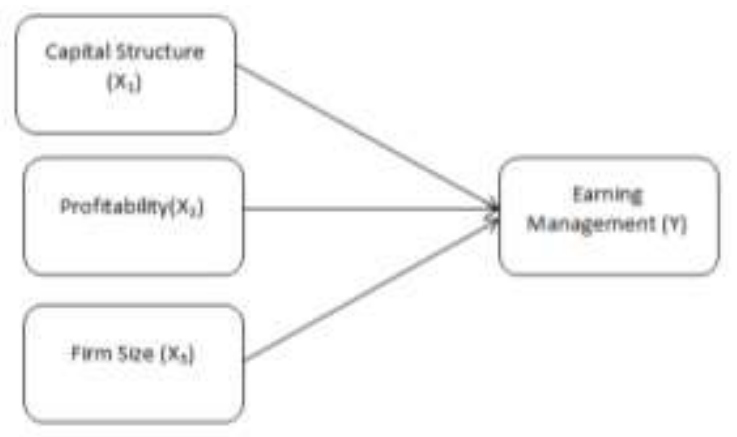

Figure 1.

\section{Hypothesis}

Framework

H1 :Capital structure has a positive and significant effect on earnings management $\mathrm{H} 2$ : Profitability has a positive and significant effect on earnings management H3 : Firm size has a positive and significant effect on earnings management

RESEARCH DESIGN AND METHOD

Operationalization of Variables and Measurement of Variables Table1. Operationalization of Variables and Measurement of Variables

\begin{tabular}{|c|c|c|c|}
\hline No & Variabel & Indicator & Scale \\
\hline 1. & $\begin{array}{l}\text { Earning } \\
\text { Management (Y) }\end{array}$ & 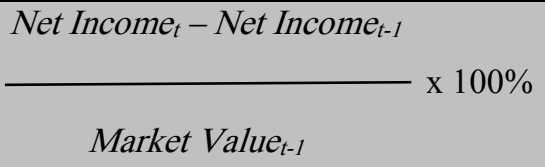 & Ratio \\
\hline 2. & $\begin{array}{l}\text { Capital structure } \\
\left(\mathrm{X}_{1}\right)\end{array}$ & $\frac{\text { Total Debt }}{\text { Total Asset }} \times 100 \%$ & Ratio \\
\hline 3. & Profitability $\left(\mathrm{X}_{2}\right)$ & $\frac{\text { EAT }}{\text { Total Asset }} \times 100 \%$ & Ratio \\
\hline 4. & Firm Size $\left(\mathrm{X}_{3}\right)$ & $\ln$ (Asset) & Nominal \\
\hline
\end{tabular}

\section{Population and Research Samples}

The population in this study are all manufacturing companies listed on the Indonesia Stock Exchange. This study uses secondary data from the financial statements of manufacturing companies in 2013 - 2017. Data in this study were taken by purposive sampling method, with the following criteria:

1. Manufacturing company

2. Publish financial statements in rupiah and issue audited financial statements as of December 31.
3. No de-listing during 2013 - 2017.

4. Have complete data following the needs of the author

\section{Data Analysis Method}

Data analysis was performed using the Eviews 8 program which included analysis as follows: 1) Test Descriptive Statistics. 2) Inferensial Statistic , Common Effect. Fixed Effect. Random Effect.3) Model Testing (Selecting the Data Panel Model); Uji Chow (F Statistik) and Haussman test. 4) Regression Testing Model 5) Feasibility Test Model 


\section{EPRA International Journal of Research and Development (IJRD)}

Volume: 5 | Issue: 5 | May 2020

consisting of Analysis of the Determination Coefficient (R2 test), Simultaneous Regression Coefficient Test (F Test) and Partial Test (t Test).

\section{RESEARCH RESULTS AND DISCUSSION}

Description of Research Object Based on data obtained from the official website of the Indonesia Stock Exchange or http://www.idx.co.id, it is known that the companies that entered the criteria in purposive sampling during the study year (20132017) were 25 companies. Criteria specified in sample selection:

Table 2. Sample Selection Results

\begin{tabular}{|l|l|c|}
\hline No & \multicolumn{1}{|c|}{ Results of Determination of Sample } & Criteria Amount \\
\hline 1 & $\begin{array}{l}\text { Manufacturing companies listed on the Indonesia Stock } \\
\text { Exchange }\end{array}$ & 154 \\
\hline 2 & $\begin{array}{l}\text { Companies that publish Annual Reports are incomplete } \\
\text { during the research year }\end{array}$ & $(27)$ \\
\hline 3 & $\begin{array}{l}\text { The company must issue a financial statement that lists } \\
\text { the values of the variables to be sent }\end{array}$ & $(62)$ \\
\hline 4 & $\begin{array}{l}\text { Publish financial statements in rupiah and issue audited } \\
\text { financial statements as of December 31. }\end{array}$ & $\mathbf{2 5}$ \\
\hline \multicolumn{1}{|c|}{$\begin{array}{l}\text { Companies that meet the criteria } \\
\text { Number of Samples (26x5years) }\end{array}$} \\
\hline
\end{tabular}

Test Assumptions and Quality of Research Instruments Descriptive statistics Table 3 Descriptive Statistics Test Results

\begin{tabular}{|l|c|c|c|c|}
\hline & $\begin{array}{c}\text { Earning } \\
\text { Management }\end{array}$ & DER & ROA & SIZE \\
\hline Mean & -0.297056 & 95.33769 & 5.936440 & 14.41197 \\
\hline Median & 0.003000 & 57.09200 & 5.449000 & 14.02700 \\
\hline Maximum & 14.87000 & 539.0170 & 25.32400 & 19.50500 \\
\hline Minimum & -26.58900 & 3.867000 & -10.73300 & 11.48000 \\
\hline Observations & 125 & 125 & 125 & 125 \\
\hline
\end{tabular}

The table above shows a general description of the descriptive statistics of the dependent and independent variables. Based on the table above, it can be explained: it is known that the number of observational data is 125 (25 Companies for the period 2013-2017) and no missing data (all data successfully processed). In the measurement of earnings management there is an average value of 0.297. This shows that manufacturing sector companies listed on the IDX make profit management with Income Minimization and are often done with taxation motivation. According to Sulistyanto (2008), Positive earnings management value, means that the company conducts earnings management by raising earnings, if the earnings management value is negative, it means that the company conducts earnings management by lowering profits, and if the earnings management value is zero / there is 1 (one) number zero behind the comma, meaning there is no indication of earnings management in the company. The largest earnings management value of 14,870 was achieved by PT. Lionmesh Prima Tbk in 2017. The minimum value of $-26,589$ was achieved by PT. Lion Metals Works Tbk.

In the Capital Structure variable, it is known that the average value is $95.33 \%$. This shows that manufacturing sector companies have a high proportion of debt compared to owned capital. This can result in high financial risk of the company and be a negative signal for investors. Companies with a high DER ratio of $539.02 \%$ achieved by PT. Jaya Pari Steel Tbk in 2015. The DER with the lowest value of $3.86 \%$ was achieved by PT. Jaya Pari Steel Tbk in 2013.

In the profitability variable represented by the ratio of return on assets (ROA) has an average value of $5.93 \%$. This shows that manufacturing sector companies are able to manage their assets to generate profits. The highest value of $25.32 \%$ was 
achieved by PT. Merck Tbk in 2014. While companies with the lowest ROA value of $-10.73 \%$ were achieved by PT. Kertas Basuki Rachmat Indonesia Tbk in 2017.

In the Firm Size variable an average value of 14.41 was achieved. The companies with the smallest company size of 11.48 achieved by PT. Kedaung Indah Can Tbk in 2014. While the company with the highest company size of 19.50 was achieved by Astra International Tbk in 2017.

\section{Selection of Panel Data Regression} Model

Before testing the influence between variables, it is necessary to select 3 (three) approaches from the panel data regression analysis. $b$.

\section{Chow Test}

Chow test is performed to determine whether the model used is a common effect (pooled least square) or fixed effect. Chow test is performed in panel data testing by selecting fixed effects in the cross section panel option. The hypothesis used:

H0: Common Effect Model is better than Fixed Effect Model

H1: Fixed Effect Model is better than Common Effect Model

The provisions that must be considered in choosing a model as follows (Ghozali, 2013: 62):

a. If the probability is $>0.05$, then $\mathrm{H} 0$ is accepted and $\mathrm{H} 1$ is rejected, or using the Common Effect Model is better than the Fixed Effect Model.

If the probability is $<0.05$, then $\mathrm{H} 0$ is rejected and H1 is accepted, or using the Fixed Effect Model is better than the Common Effect Model.

Table 4 Chow Test Results

Redundant Fixed Effects Tests

Equation: Untitled

Test cross-section fixed effects

\begin{tabular}{lrrr}
\hline \hline Effects Test & Statistic & d.f. & Prob. \\
\hline \hline Cross-section F & 2.198862 & $(24,97)$ & 0.0037 \\
Cross-section Chi-square & 54.300960 & 24 & 0.0004 \\
\hline \hline
\end{tabular}

Test results Table 4 above shows that the probability value of 0,000 or $<0.05$ so it can be concluded that $\mathrm{HO}$ is rejected and $\mathrm{H} 1$ is accepted, or using the Fixed Effect Model is better than the Pooled least square Model.

\section{Haussman Test}

The Haussman test is used to determine. whether the right model is the fixed effect model or the random effect model. In this study the Haussman test was performed in panel data testing by selecting. a random effect on the cross section option. The provisions that must be considered in choosing a model are as follows:
The hypothesis used:

H0: The random effect model is better than the Fixed Effect Model

H1: Fixed Effect Model is better than Random effect Model

The provisions that must be considered in choosing a model as follows (Ghozali, 2013: 64):

If probability $>0.05$, then $\mathrm{H} 0$ is accepted and $\mathrm{H} 1$ is rejected or using the Random effect Model is better than the Fixed Effect Model

b. If the probability is $<0.05$, then $\mathrm{H} 0$ is rejected and H1 is accepted or using the Fixed Effect Model is better than the Random effect Model 


\section{EPRA International Journal of Research and Development (IJRD)}

Volume: 5 | Issue: 5 | May 2020

Table 5 Haussman Test Results

Correlated Random Effects - Hausman Test

Equation: Untitled

Test cross-section random effects

\begin{tabular}{lrrr}
\hline \hline Test Summary & $\begin{array}{r}\text { Chi-Sq. } \\
\text { Statistic }\end{array}$ & Chi-Sq. d.f. & Prob. \\
\hline \hline Cross-section random & 26.375986 & 3 & 0.0000 \\
\hline \hline
\end{tabular}

Test results Table 5 above showa that the probability value of 0,000 or $<0.05$ so it can be concluded that $\mathrm{H} 0$ is rejected and $\mathrm{H} 1$ is accepted or using the Fixed Effect Model is better than the Random effect Model.

\section{Regresion Data Panel Results}

In this study panel data regression analysis (panel regression model) was used. That is because the data in this study are a combination of cross section and time series data. Through panel data analysis testing, researchers will find out the influence between the variables tested to answer the problem formulation and research hypotheses. The following are the results of the panel data regression analysis in the study.

\section{Tabel 6 Regresion Data Panel Results Fixed Effect Methode}

Dependent Variable: Earning Management

Method: Panel Least Squares

Date: 09/03/19 Time: 07:22

Sample: 20132017

Periods included: 5

Cross-sections included: 25

Total panel (balanced) observations: 125

\begin{tabular}{ccccc}
\hline \hline Variable & Coefficient & Std. Error & t-Statistic & Prob. \\
\hline \hline C & 34.15158 & 22.87443 & 5.493002 & 0.0000 \\
DER & 0.531488 & 0.007720 & 4.078609 & 0.0001 \\
ROA & 0.388338 & 0.101146 & 3.839383 & 0.0002 \\
SIZE & 1.980796 & 1.579491 & 2.254072 & 0.0028 \\
\hline \hline
\end{tabular}

Cross-section fixed (dummy variables)

\begin{tabular}{lrlr}
\hline \hline R-squared & 0.865111 & Mean dependent var & -0.297056 \\
Adjusted R-squared & 0.788389 & S.D. dependent var & 3.588893 \\
S.E. of regression & 3.233214 & Akaike info criterion & 5.379228 \\
Sum squared resid & 1014.006 & Schwarz criterion & 6.012770 \\
Log likelihood & -308.2017 & Hannan-Quinn criter. & 5.636602 \\
F-statistic & 8.066022 & Durbin-Watson stat & 1.702203 \\
Prob(F-statistic) & 0.000025 & & \\
\hline
\end{tabular}

Based on table 6, the following is an explanation of the panel data regression test:

In the best capital selection, panel data regression model used is fixed effect. This is based on the results of the model selection through the chow test and the haussman test. The results of selecting a research model can be seen in the appendix. Based on this, here is the equation of the research model.

$\mathrm{Y}=34,151+0.531 \mathrm{X} 1+0.388 \times 2+1,980 \mathrm{X} 3+\mathrm{e}$

Constant value of 34,151 with a significance value of 0,000 . Due to the significance $<0.05$, the value of the constant and can be interpreted that if all the independent variables are considered constant or 
unchanged, the amount of Profit Management is 34,15 .

The capital structure regression coefficient value of 0.531 with a significance value of 0.000 . This shows that there is a significant influence. The regression coefficient number shows that if the Capital Structure increases by one unit, the Profit Management will increase by 0.531 .

The profitability regression coefficient value is 0.388 with a significance value of 0.000 . This shows that there is a significant influence. The regression coefficient number indicates that if profitability increases by one unit, the Profit Management will increase by 0.531 .

Regression coefficient of Firm Size is 1,980 with a significance value of 0.002 . This shows that there is a positive and significant influence. The regression coefficient number shows that if the size of the company increases by one unit, the Profit Management will increase by 1,980

The coefficient of determination (RSquared) is 0.865 . This shows that the percentage contribution of the influence of the independent variable on the dependent variable is $86.5 \%$. In other words, it can be interpreted that the independent variables (Capital Structure, Profitability and Company Size) used in this study were able to explain the dependent variable Profit Management of $86.5 \%$. While the remaining $13.5 \%$ is influenced by other variables.

\section{F Test}

The $\mathrm{F}$ test is used to test whether the independent or independent variables entered in the model have a joint effect on the dependent variable (Ghozali, 2013). If Fcount $>$ Ftable and $F$ have a significant value $<0.05$, the hypothesis is accepted, meaning the hypothesis is proven. If Fcount $<$ Ftable and $\mathrm{F}$ have a significant value $>0.05$, the hypothesis is rejected, meaning the hypothesis is not proven.Criteria for decision making are as follows: accepted

If Fcount $>$ from Ftable, $\mathrm{H} 0$ is rejected. Ha If Fcount $<$ from Ftable, H0 is accepted. Ha rejected

Based on table 6 it is known that the Fcount value is $8,066>$ Ftable 2,680 and the probability is $0,000<0.05$ (Ghozali, 2013: 71). Based on this, it can be concluded that the Capital Structure (DER), Profitability (ROA) and Firm Size (SIZE) simultaneously (Together) have a significant effect on earning Management.

\section{T Test}

The $\mathrm{t}$ test basically shows how far the influence of the explanatory / independent variables individually in explaining the dependent variation (Ghozali, 2013). If tcount $>$ ttable and $t$ have a significance $<0.05$, the hypothesis is accepted, meaning the hypothesis is proven. If tcount $<$ ttable and $\mathrm{t}$ have a significant value $>0.05$ then the hypothesis is rejected, meaning the hypothesis is not proven. Criteria for decision making are as follows: accepted

If $\mathrm{t} \gg \mathrm{t}$ table then $\mathrm{H} 0$ is rejected. $\mathrm{Ha}$ rejected

If tcount $<$ of table then $\mathrm{H} 0$ is accepted. Ha

Based on the panel data regression test results, here are the results of the t test (hypothesis test) in this study. So it can be concluded that $\mathrm{HO}$ is rejected, Ha is accepted or hypothesis 3 is accepted.

\section{DISCUSSION \\ Effect of Capital Structure on Earnings Management}

Based on research results, it is known that the Capital Structure has a positive and significant effect on Earnings Management. Capital structure in business organizations consists of two sources, namely equity and debt. The use of debt in a company's capital structure differs from country to country, industry to another, and also from company to company in the same industry and in the same country, depending on funding needs, and whether current shareholders have the will and ability to provide for the company's funding needs (Riyanto, 2013).

Horne and Wachowicz (2013) which states that it is important to determine how much debt and capital a company has to determine the level of debt use as a source of corporate financing that includes both short-term and long-term obligations in assessing financial performance. In addition, the increase in debt will affect the size of the net profit available to shareholders including dividends received because the obligation to pay debts takes precedence over dividend distribution (Riyanto, 2013). This can encourage management in carrying out earnings management practices because the company must finance the shareholders with the profits obtained, so the company must maximize the use of capital to get the maximum profit. So the company will get a good image of investors who survive or will come so they will continue to invest in the company. The results of this study are in line with research conducted by Nikoomaram, et al (2016) and Agustia and Elly (2018) that capital structure has a positive and significant effect on earnings management. 


\section{Effect of Profitability on Earnings Management}

Based on research results, it is known that profitability has a positive and significant effect on earnings management. Profitability is the company's ability to generate profits, the greater the profitability, the greater the management's ability to manage company assets to generate profits. This can influence investors to predict earnings and risks in their investments which have an impact on investor confidence in the company (Trisnawati, 2015).

Profitability shows the ability of management to manage profits. Companies that get big profits will try to maintain or even increase the amount of their income to prosper the company and investors. Besides that investors also want the stability of the company in making a profit. Therefore, management is motivated to practice earnings management. So this can increase investor confidence (Jogiyanto, 2015).

\section{Effect of Company Size on Profit Management}

Based on the results of the study, it is known that company size has a positive and significant effect on earnings management. Firm Size is a scale that can be classified in large or small companies. Basically the size of the company is only divided into two categories, namely large companies (large firm) and small companies (small firm). The determination of the size of the company is based on the company's total assets (Riyanto, 2013).

Large companies have a broader stakeholder base, so that various large company policies will have a greater impact on the public interest compared to smaller companies. For investors, company policy will have implications for the prospect of large cash flows for the public interest compared to small companies (Jogiyanto, 2015).

\section{CONCLUSIONS AND RECOMMENDATIONS Conclusion}

Based on the results of the analysis conducted in this study, it can be concluded that: 1) Capital structure has a positive and significant effect on earnings management.2) Profitability has a positive and significant effect on earnings management. 3) Firm size has a positive and significant effect on earnings management.

\section{Suggestion}

Based on the conclusions above, the following are suggestions made in this study.

a. For investors as capital owners can find out the earnings management signals made by the company through the movement of capital structure, profitability and company size that is not reasonable. In this case, the increase or decrease in financial performance is too sharp in a period.

b. For the Indonesia Stock Exchange to tighten supervision of financial reports provided by companies listed on the Indonesia Stock Exchange. The audit process on financial performance, especially on capital structure, profitability and company size needs to be carried out strictly to minimize the possibility of earnings management practices

c. For company management, it is advisable to avoid earnings management practices. This is intended so that the company still has a good reputation in the eyes of shareholders and potential investors so that the funds that have been invested in the company are not withdrawn and can continue to attract interest for potential investors for the company's sustainability in the future. By avoiding earnings management practices, the company's credibility will increase thus creating a competitive advantage in similar industries.

d. The next research is expected to expand the research year or period so that the influence can be seen from a longer period of time

e. For future research, it is expected to be able to test a number of variables or add other variables that are suspected to have an influence on earnings management such as the company's ownership structure, audit quality and others.

\section{REFERENCES}

1. Aditama, Ferry dan Anna Purwaningsih. 2014. "Pengaruh Perencanaan Pajak terhadap Manejemen Laba pada Perusahaan Non Manufaktur yang Terdaftar di Bursa Efek Indonesia”. Jurnal Modus. Vol. 26 No. 1.

2. Agustia, Yofi Prima dan Elly Suryani. 2018. "Pengaruh Ukuran Perusahaan, Umur Perusahaan, Leverage, dan profitabilitas terhadap manjemen Labal Studi Pada Perusahaan Pertambangan yang Terdaftar di Bursa Efek". Jurnal Administrasi Bisnis. Vol. 10 No. 1.

3. Ali, Usman., Muhammad Kashif Khurshid., dan Akhtar Mahmood. 2015. "Impact of Firm Size on Earnings Management; A Study of Textile Sector of Pakistan". European Journal of Business and Management. Vol. 7 No. 28. 
4. Amelia, Winda dan Erna Hernawati. 2016. "Pengaruh Komisaris Independen, Ukuran Perusahaan dan Profitabilitas terhadap Manajemen Laba". Jurnal Neobis. Vol. 10 No. 1

5. Azlina, Nur. 2010. "Analisis Faktor yang Mempengaruhi Manajemen Laba (Studi pada Perusahaan yang Terdaftar di BEI)". Pekbis Jurnal. Vol.2 No.3.

6. Bassiouny, Sara W., Mohamed Moustafa Soliman., and Aiman Ragab. 2016. "The impact of firm characteristics on earnings management: an empirical study on the listed firms in Egypt". The Business and Management Review. Vol. 7 No. 2

7. Brigham, Eugene F and Joel F. Houston. 2009. Fundamentals of Financial Management. 12th Edition. Mason: South-Westtern Cengage Learning.

8. Dini, Maya dan Nurhayati. 2015. "Pengaruh Kinerja Keuangan Terhadap Return Saham Pada Perusahaan Manufaktur Yang Terdaftar Di Bursa Efek Indonesia”. Jurnal Akuntanika. Vol. 1 No. 1 .

9. Fahmi, Irham. 2016. Analisis Laporan Keuangan. Bandung: CV Alfabeta.

10. Ghozali, Imam. 2013. Aplikasi Analisis Multivariate dengan Program IBM SPSS 21 Update PLS Regresi. Semarang: Badan Penerbit Universitas Diponegoro.

11. Godfrey, T. 2014. Accounting Theory. Australia: John Wiley \& Sons Australia.

12. Hanafi, Mamduh M dan Abdul Halim. 2016. Analisis Laporan Keuangan. Edisi Kelima. Yogyakarta: UPP STIM YKPN.

13. Harahap Sofyan Syafri. 2011. Teori Akuntansi. Edisi Revisi 2011. Jakarta: Rajawali Pers.

14. Hartanto. 2011. Analisis Laporan Keuangan. Edisi pertama. Cetakan keempat. Yogyakarta: AMP YKPN.

15. Hasty, Ayu Dwi dan Vinola Herawaty. 2017. "Pengaruh Struktur Kepemilikan, Leverage, Profitabilitas dan Kebijakan Dividen terhadap Manajemen Laba dengan Kualitas Audit sebagai variabel Moderasi". Jurnal Media Riset Akuntansi, Auditing \& Informasi. Vol. 17 No. 1

16. Halim, Abdul. 2015. Auditing (Dasar-dasar Audit Laporan Keuangan). Jilid 1. Edisi Kelima. Yogyakarta: UPP STIM YKPN.

17. Hariyani, Iswi., R. Serfianto., dan Cita Yustisia. 2011. Merger, Konsolidasi, Akuisisi, \& Pemisahan Perusahaan - Cara Cerdas Mengembangkan dan Memajukan Perusahaan. Jakarta: Visimedia.

18. Hery,S.E. 2012. Analisis Laporan Keuangan. Jakarta: PT.Bumi Aksara.

19. Husnan, Suad. 2015. Dasar-Dasar Teori Portofolio dan Analisis Sekuritas. (Edisi 5). Yogyakarta : UPPN STIM YKPN

20. Indracahya, Erik dan Sewi A. Faisol. 2017. "The Effect of Good Corporate Governance Elements, Leverage, Firm Age, Company Size and Profitability on Earning Management (Empirical
Study of Manufacturing Companies in BEI 20142016)". Jurnal Profita. Vol. 10 No. 2.

21. Jensen, Michael C. dan Meckling. William H., 1976, "Theory of The Firm: Managerial Behavior, Agency Cost, and Ownership Structure". Jurnal of Financial Economics. Vol. 3 No. 4

22. Jogiyanto, Hartono, 2013. Teori Portofolio dan Analisis Investasi. Yogyakarta: BPFE.

23. Kasmir. 2011. Analisis Laporan Keuangan. Jakarta: Raja Grafindo Persada.

a. . 2013. Analisis Laporan Keuangan. Rajawali Pers : Jakarta.

24. Khanh, Hoang Thi Mai and Nguyen Vinh Khuong. 2018. "Audit Quality, Firm Characteristics and Real Earnings Management: The Case of Listed Vietnamese Firms". International Journal of Economics and Financial Issues. Vol. 8 No. 4

25. Kieso, D. E. 2011. Intermediate Accounting. United States of America : Wiley

26. Kingsley, Omimi- Ejoor Osaretin., Favour Osaro., Enegbe O. Precious., and Efosa Collins. 2016. "Determinants of Earnings Management in Nigerian Quoted Companies". Igbinedion University Journal of Accounting. Vol. 1

27. Kumari, Prity and J.K. Pattanayak. 2015. "Earnings management and firm performance: an insight into Indian commercial banks". Journal of Scientific Research and Development. Vol. 2 No. 11

28. Mahawyahrti, P. T., dan Budiasih, I. G. 2016. "Asimetri Informasi, Leverage, Dan Ukuran Perusahaan Pada Manajemen Laba”. Jurnal Ilmiah Akuntansi dan Bisnis. Vol. 17 No. 1.

29. Martani, Dwi. 2012. Akuntansi Keuangan Menengah Berbasis PSAK. Jakarta: Salemba Empat.

30. Minaari, Ivonne S. Saerang, Joubert B. Maramis. 2018. "Pengaruh Diversifikasi dan Manajemen Laba terhadap Struktur Modal (Studi pada Perusahaan Subsektor Food and Beverages yang terdaftar di BEI)". Jurnal Emba. Vol. 6 No. 3

31. Mulyana, Ayu., Zuraida., and Mulia Saputra. 2018. "The Influence of Liquidity, Profitability and Leverage on Profit Management and Its Impact on Company Value in Manufacturing Company Listed on Indonesia Stock Exchange Year 2011-2015". International Journal of Managerial Studies and Research (IJMSR). Vol. 6 Issue. 1.

32. Naz, Iram., Khurram Bhatti., Abdul Ghafoor., and Habib Hussain Khan. 2016. "Impact of Firm Size and Capital Structure on Earnings Management: Evidence from Pakistan". International Journal of Contemporary Business Studies. Vol. 2 No. 12

33. Nikoomaram, Hashem., Farhad Arabahmadi., and Aliasghar Arabahmadi. 2016. "The Relationship between earning management and capital structure". International Journal of Finance and Managerial Accounting. Vol. 1 No. 1 


\section{EPRA International Journal of Research and Development (IJRD)}

34. Prasetyantoko, A. 2008. Corporate Governance; Pendekatan Institusional. Jakarta: PT. Gramedia Pustaka Utama.

35. Prastowo D, Dwi. 2015. Analisis Laporan Keuangan. Yogyakarta: UPP STIM YKPN.

36. Rahmayanti, E. 2012. "Analisis Pengaruh Mekanisme Coprorate Governance terhadap Manajemen dan Kinerja Perusahaan”. Skripsi. Universitas Indonesia

37. Richardson, V.J. 1998. "Information Asymmetry and Earnings Management: Some Evidence." Dissertation. University of Kansas, March.

38. Riyanto, Bambang. 2013. Dasar-Dasar Pembelanjaan Perusahaan. Edisi Keempat. BPFE-Yogyakarta. Yogyakarta

39. Samryn. L. M. 2012. Pengantar Akuntansi. Jakarta: PT. Raja Grafindo Persada.

40. Sartono, Agus. 2015. Manajemen Keuangan: Teori dan Aplikasi. Edisi Keempat. Yogyakarta: BPFE.

41. Sawir, Agnes. 2009. Analisa Kinerja Keuangan dan Perencanaan keauangan Perusahaan. Jakarta : PT. Gramedia Pustaka Utama.

42. Subramanyam dan John J. Wild. 2012. Analisis Laporan Keuangan. Jakarta: Salemba Empat.

43. Scott, William R. 1997. Financial Accounting Theory. New Jersey: Prentice Hall.

44. Sugiyono. 2013. Metode Penelitian Pendidikan Pendekatan Kuantitatif, Kualitatif, dan $R \& D$. Bandung: Alfabeta.

45. Suhartanto, Dwi. 2015. "Pengaruh Ukuran Perusahaan, Profitabilitas, Leverage, Kepemilikan Publik, Perubahan Harga Saham, dan Risiko Bisnis terhadap Manajemen Laba pada Perusahaan Publik Sektor Keuangan”. Jurnal Ekonomi Bisnis. Vol. 20 No. 1

46. Sulistyanto, H. Sri. 2014. Manajemen Laba: Teori dan Metode Empiris. Jakarta: PT. Grasindo.

47. Sutrisno, Edi. 2009. Manajemen Sumber Daya Manusia Edisi pertama. Jakarta: Kencana Prenada Media Group.

48. Sunarto. 2009. Auditing. Yogyakarta: BPFE.

49. Syamsuddin, 2009. Manajemen Keuangan Perusahaan. Jakarta: Penerbit PT. Raja Grafindo Persada.

50. Torang, Syamsir. 2012. Metode Riset Struktur Dan Perilaku Organisasi. Bandung: Alfabeta.

51. Uwuigbe, Uwalomwa., Uwuigbe Olubukunola Ranti., and Okorie Bernard. 2015. "Assesment of the Effects of Firm Characteristics on Earning Management of Listed Firms in Nigeria". Asian Economic and Financial Review. Vol. 5 No. 2.

52. Vakilifard, Hamidreza and Mahboobe Sadat Mortazavi. 2016. "The Impact of Financial Leverage on Accrual-Based and Real Earnings Management". International Journal of Academic Research in Accounting, Finance and Management Sciences. Vol. 6 No. 2.

53. Wardani, Dewi Kusuma dan Pipit Dayu Isbela. 2017. "Pengaruh Strategi Bisnis dan Karakteristik Perusahaan terhadap Manajemen
Laba”. Jurnal Riset Akuntansi dan Keuangan Fakultas Bisnis. Vol. 13 No. 2

54. Weston, J. Feed dan Thomas E. Copeland. 2010. Manajemen Keuangan. Jakarta: Binarupa Aksara.

55. Widianingrum dan Sunarto. 2018. "Deteksi Manajemen Laba: Leverage, Free Cash Flow, Profitabilitas dan Ukuran Perusahaan (Studi Kasus pada Perusahaan Manufaktur yang Terdaftar di BEI Periode 2013-2016)”. Prosiding Sendi.

56. Yusrilandari, Larinka Putri., Dini Wahjoe Hapsari., dan Dewa Putra K.M. 2016. "Pengaruh Profitabilitas, Kepemilikan Manajerial dan Ukuran Perusahaan terhadap Manajemen Laba (Studi Kasus pada Perusahaan Sektor Industri Barang Konsumsi yang Terdaftar di Bursa Efek Indonesia Periode 2012-2015)". eProceeding of Management. Vol. 3 No. 3 